\title{
PReS-FINAL-2216: Biomarkers MRP8/14 and S100A12 correspond with flare and remission clinical status in Sojia patients in the AID-NET register
}

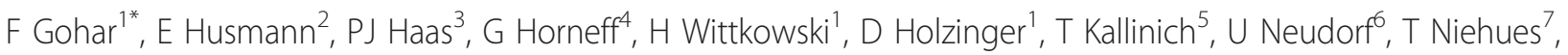 \\ E Lainka $^{8}$, D Foell ${ }^{1}$
}

From 20th Pediatric Rheumatology European Society (PReS) Congress

Ljubljana, Slovenia. 25-29 September 2013

\section{Introduction}

Systemic onset juvenile idiopathic arthritis (SoJIA) shows properties of autoinflammatory disease, and requires the presence of arthritis and fever for diagnosis. The proinflammatory proteins MRP8/14 (S100A8/9) and S100A12 are biomarkers which have been shown to detect ongoing subclinical disease activity in patients with clinical remission. We compared the MRP8/14 (S100A8/9) and S100A12 biomarker profile of patients in the AID-NET (German Auto-inflammatory Disease Network) register to further provide evidence for the usefulness of measurement of these biomarkers.

\section{Objectives}

To characterize levels of pro-inflammatory markers of innate immune activation, S100A12 and MRP8/14, during active and inactive disease status of patients with SoJIA.

\section{Methods}

The AID-Net register, which includes patients with SoJIA diagnosed according to ILAR criteria, was searched for patients with clinically defined remission and flare episodes. Patients in remission were those documented as being either: 'non-acute', in remission, or with a clinician score of $<1$ (range $0-10$, where 0 represents inactivity and 10 represent highly active disease). Flares were any cases

'Department of Paediatric Rheumatology and Immunology, University of Muenster, Muenster, Germany

Full list of author information is available at the end of the article scored as 'flare' or 'acute'. Statistical significance was measured using the Mann-Whitney-U test, using SPSS.

\section{Results}

55 patients with a median age of 13 years (range 520 years) at time of blood sampling were included. A total of 158 episodes occurred where disease activity status and MRP8/14 and S100A12 results were available. This included 38 episodes of flares (19 patients) and 120 episodes of remission (44 patients). Patients presenting with episodes of flare had significantly higher mean S100A12 values compared with patients in remission (mean 2,895 (range 15-19,410) ng/ml vs 575 (0-6,220) $\mathrm{ng} / \mathrm{ml}$, respectively, $\mathrm{p}-<0.01)$. MRP $8 / 14$ values were also higher in patients who were clinically flaring than in those in remission $(9,600(100-48,610) \mathrm{ng} / \mathrm{ml}$ vs 2,965 $(0-45,390) \mathrm{ng} / \mathrm{ml}, \mathrm{p}<0.01)$.

\section{Conclusion}

The measurement of MRP8/14 and S100A12 biomarkers in patients with SoJIA in the AID-net register corresponded well with the recorded clinical disease activity in these patients. This provides further evidence for the measurement of these biomarkers.

References: 1) Foell D et al. Methotrexate withdrawal at 6 vs 12 months in juvenile idiopathic arthritis in remission: a randomized clinical trial. JAMA 2010;303:1266-73. 2) Gerss J et al. Phagocyte-specific S100 proteins and highsensitivity $\mathrm{C}$ reactive protein as biomarkers for a riskadapted treatment to maintain remission in juvenile idiopathic arthritis: a comparative study. Ann Rheum Dis 2012;71:1991-7. 


\section{Disclosure of interest}

None declared.

\section{Authors' details}

${ }^{1}$ Department of Paediatric Rheumatology and Immunology, University of Muenster, Muenster, Germany. 'University Children's Hospital, Children's Unit, Paediatric Rheumatology, Essen, Germany. ${ }^{3}$ German Center for Child and Adolescent Rheumatology, Garmisch-Partenkirchen, Garmisch-Partenkirchen, Germany. ${ }^{4}$ Center of General Paediatrics and Neonatology, Asklepios Clinic Sankt Augustin $\mathrm{GmbH}$, Sankt Augustin, Germany. ${ }^{5}$ Department of Pediatric Pneumology and Immunology, Department of Rheumatology, Charité Universitätsmedizin Berlin, Berlin, Germany. ${ }^{6}$ Paediatric Rheumatology, University of Duisburg-Essen, Essen, Germany. ${ }^{7}$ Center for Child and Adolescent Medicine, HELIOS Hospital Krefeld, Krefeld, Germany.

${ }^{8}$ Paediatric Rheumatology, University Hospital Essen, Children's Hospital, Essen, Germany.

Published: 5 December 2013

doi:10.1186/1546-0096-11-S2-P206

Cite this article as: Gohar et al:: PReS-FINAL-2216: Biomarkers MRP8/14 and S100A12 correspond with flare and remission clinical status in Sojia patients in the AID-NET register. Pediatric Rheumatology 2013 11(Suppl 2): P206.

\section{Submit your next manuscript to BioMed Central} and take full advantage of:

- Convenient online submission

- Thorough peer review

- No space constraints or color figure charges

- Immediate publication on acceptance

- Inclusion in PubMed, CAS, Scopus and Google Scholar

- Research which is freely available for redistribution

Submit your manuscript at www.biomedcentral.com/submit
Ciomed Central 